\title{
Prediction of Land use and Land Cover Change in Panjin City based on Clue-S Model
}

\author{
Jiujun LV \\ Liaoning Provincial Academy of Environmental Sciences, Shenyang, China
}

\begin{abstract}
KEYWORD: Clue-S model, Simulation, Panjin
ABSTRACT: The study discussed the feasibility of CLUE-S model in Panjin in two different scenarios. Results showed that driving forces of land use in the model could simulated the land use in Panjin well, including slope, aspect, distance from river, density of population and so on. In the simulation in Panjin for 2018, two scenarios were designed. By comparison of the two scenarios, the land use pattern of environmental protection mode was better than development following existing trends mode. The simulations could be the important references for future land use plan.
\end{abstract}

KEYWORD: Clue-S model, Simulation, Panjin

\section{INTRODUCTION}

Land use and land cover (LUCC) change is an important indicator of human activities through its influens on biodivesity, water, and radiation budgets, trace gas emissions, carbon cycling, and livelihoods (Liu et al., 2009, Verburg et al., 2002, Larmbin et al., 2000). The Study of causes, processes, and cosequences of LUCC is recognized as a current research frontier in ecosystem management(Wu and Hobbs, 2002). As well, land use planning and management substaintially is to predict land use changes based on different scenarios and to choose the best one for applying. Although many researchers studying on land use have different disciplinary background, they all realize that understanding and modeling land use driving factors of different spatial and temporal scales determin the location of land use simulation (Thompson et al.,2002). In addition, land use analysis can help to assess the impact on nature resources. The needs of spatially explict land use models has led to the develop of a wide range of land use change models. Clue-S model is one of these models which considering combination of economic and social driving factors(Turner, 1994). And the model could simulate future land use changes for land use planning. This study was designed to examine LUCC in Panjin city based on Clue-S model. Such a case study may be helpful for decision makers to make useful policy-making of land use planning.

\section{MATERIALS AND METHODS}

\section{Study Area}

Panjin $\left(40^{\circ} 39^{\prime}-41^{\circ} 27^{\prime} \mathrm{N}, 121^{\circ} 25^{\prime}-122^{\circ} 31^{\prime} \mathrm{E}\right)$ is located at the central of Liaohe River Delta of Liaodong Bay with the area about $4084 \mathrm{~km}^{2}$. 


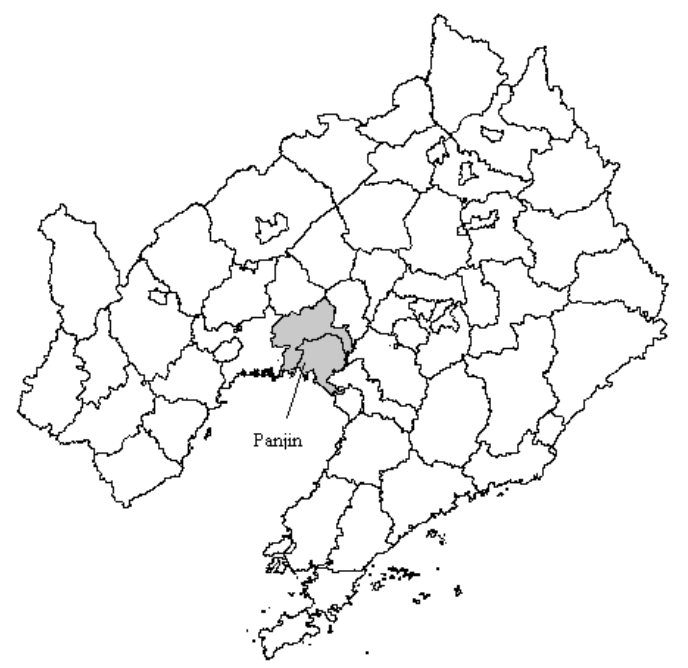

Figure 1. Location map of the study area(Panjin).

Panjin area is a temperate continental climate, with hot rainy season. The annual average temperature and frost-free period are $8.4^{\circ} \mathrm{C}$ and $170 \mathrm{~d}$. And the rainfall is $623.2 \mathrm{~mm}$. In this area, the alluvial plain and tidal flat are the main landtypes. The main avantage community is reed wetland with the area about $800 \mathrm{~km}^{2}$. In the intertidal belt, suaeda heteroptera spreads widely. Seashore Saline soil is the main soil media in the region.

\section{Data Preparation}

Satellite image in 1988(Landsat MSS, resolution: 79m), 1998 and 2008 (Landsat TM, resolution: 30m)were used to derive land use as seven types: paddy field, dry farm, reed mash, ponds, river, forest land and built-up areas. All classification results of the three images were resample to the resoltution of $80 \mathrm{~m}$. Driving forces of the land use in Panjin were selected including natural factors and social-economic factors as follows:

Table 1. The selected dring factors

\begin{tabular}{cc}
\hline Types of Factors & Factors \\
\hline & Slope \\
Aspect \\
Natural Factors & Distance from Coastal \\
& Distance from River \\
& Distance from Settlement \\
& Distance from Road \\
\hline Social-Economic & Density of Population \\
Factors & Density of Rural Population \\
\hline
\end{tabular}

\section{Research Methods}

\section{Model description}

Future land use/cover was predicted with the CLUE-S model, which is a land use change prediction model that has been used and validated in a wide range of applications(Veldkamp et al., 2001; Verburg and Veldkamp, 2004). The model is divided into a spatial module and a non-spatial module. The non-spatial module calculates the demands for land-uses based on analyses of driving factors. Meanwhile, the spatial module translates these demands into land-use changes. Fore more details, the study of Verburg et al.(2002) had expounded minutely.

\section{Model validation}

ROC validation. ROC (relative operating characteristic ) test statistic is to determine if the land use could be explained by 7 driving variables well in our study. The driving factors and land use types for each raster cell were transformed into an ASCII format. The ASCII data were further transformed by 
CLUE-S into a column format. Then, the data were analyzed by binary logistic regression to determine the relationship between each land use type and the factors.

Simulation validation. Prediction results of Clue-S model were determined by Applicability of the models in Panjin. To assess the accuracy and feasibility of the model, the study would use the 1988 and 1998 land use pattern derived from the satellites as the input variables to simulate 2008 land use. The simulation results of 2008 would be compared with the one interpreted from TM image by Kappa index (Pontius 2000). Kappa statistics could be used to assess the similarity of two images. If the value computed by Kappa greater than 0.75, the two image are similar and change slightly. Therefore, the Clue-s model accuracy would be assess by the method in Panjin.

\section{Scenarios Design}

If the Clue-S model was available in Panjin, two scenarios of socia-economic factors would be taked account for prediction Panjin future land cover in 2018. The scenarios of simulation includes history trend (HT, development following existing trends mode) and environmental protection mode (EP). In HT, land use change trend would determine by land use conversion from 1998 to 2008. The land use demand determined by the calculation of the history data(Table 2). In EP, the land use demand would determine by local policies of land use which taked ecological protection and intensive land use into account(Table 2). After the design, the land use will be simulated and predicted.

Table 2 Land use demands of 2018 in two scenarios

\begin{tabular}{ccc}
\hline & HT Mode & EP Mode \\
\hline Paddy field & 198801 & 149051 \\
Dry farmland & 31678 & 21682 \\
River & 5724 & 6910 \\
Built-up area & 50551 & 50038 \\
Forest land & 2768 & 17015 \\
Pond & 4496 & 5972 \\
Reed mrash & 86102 & 130888 \\
\hline
\end{tabular}

\section{RESULTS}

\section{Simulation accuracy}

The logistic regression results were evaluated using the ROC. If the ROC was greater than 0.7 , a good explanatory by the seven driving factors for land use were suggested. The ROCs (Table 2) were greater than 0.7 for all land-use types, suggesting successful correlations and strong powers to explain the land-use patterns by the driving factors. And the driving factor could be used in subsequent experiments.

Table 3. ROCs of different land use types by driving factors explained.

\begin{tabular}{cc}
\hline Land use types & ROC \\
\hline Paddy field & 0.709 \\
Dry farm & 0.810 \\
Reed mash & 0.821 \\
Ponds & 0.747 \\
River & 0.729 \\
Forestland & 0.731 \\
Built-up areas & 0.812 \\
\hline
\end{tabular}

To analysize the results by the simulation of the model, Kappa index was used to compare the simulation of 2008 by the model and the land use from TM imagery. The calculation of Kappa is 0.83, 
which means the simulation and actural land use was similar. Therefore, the Clue-S model was feasible for predicting the near future land use. The simulation and actural land use were showed as Figure 2.
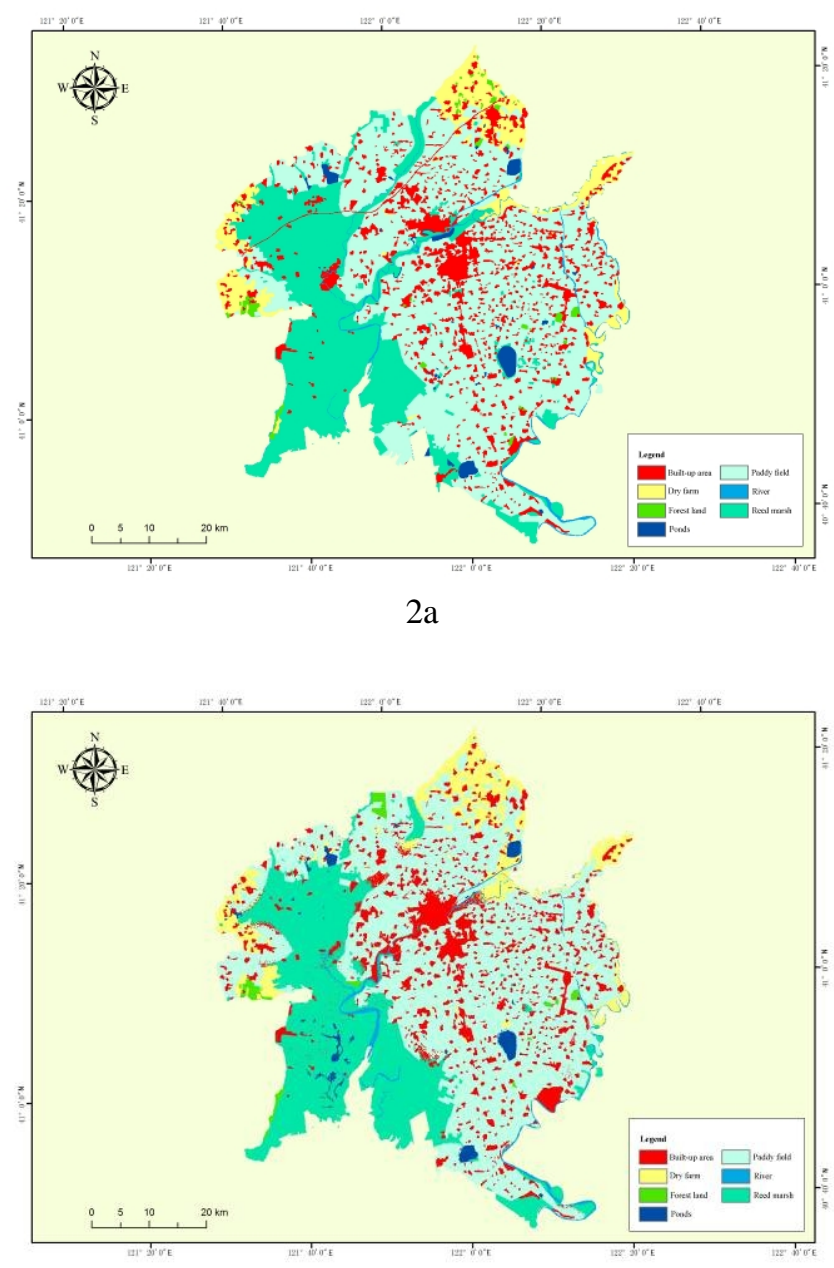

$2 b$

Figure 2. 2008 Land use maps in Panjin by TM imagery intepreted and Clue-S model simulated. Figure 2a was from TM; Figure 2b was Clue-S model.

\section{Simulation results}

The land-use maps in 2018 (Fig.3) were simulated from the actual data for 2008 assuming two scenario modes. 


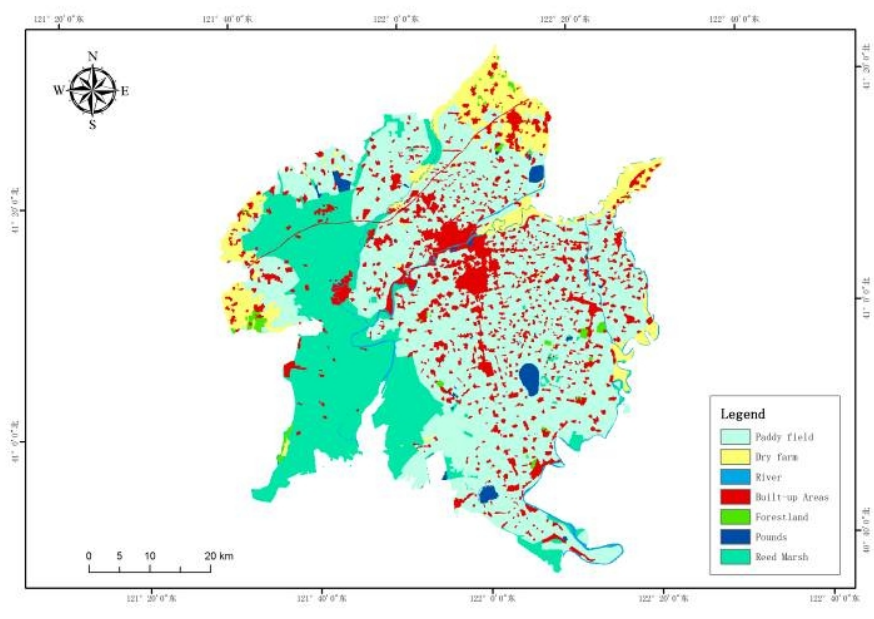

$3 \mathrm{a}$

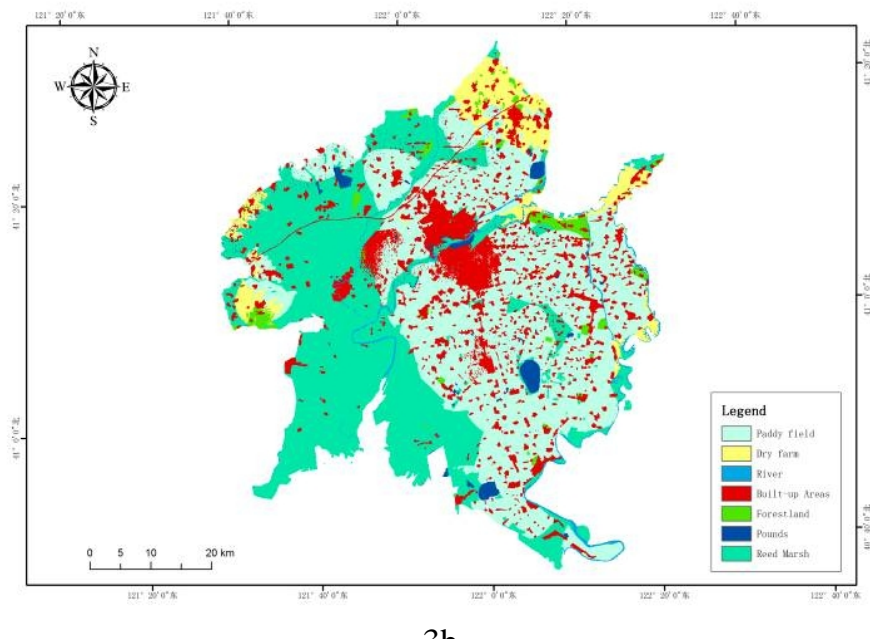

$3 \mathrm{~b}$

Figure 3. Simulated land-use maps of Panjin in 2018 assuming two development modes: assuming development following existing trends (3a); assuming development environmental protection mode (3b).

In HT (development following existing trends) mode, areas of river, ponds and reed mash were declining persistently. Among these land use types, built-up areas were expect to increase and fragment in reed mash, dry farm and other land-use types. In addition paddy field would occupy a lot of reed mash in the south of Panjin. The two changes would lead to the reduce of natural ecosysytem and the fragmentation of all land use in Panjin. Also, areas of human activites such as built-up areas and paddy fields would expaned sustaintly by occupying natural ecosystems and others. The habitat of waterflows depending on reed marsh and ponds would threatened as these changes.

In EP (environmental protection mode), the land use of reed mash would increase and expan in both the south and the north of Panjin next to original reed marsh, because the change fo paddy filed becoming reed marsh. The built-up in EP were expected to be more concentrated on the basis of original built-up areas in 2008. By these changes, habitat of wild waterflows would be increased and completed. The ecosystems pattern of Panjin were better in EP than HT. The EP simulation results could be used to guide future use plan and natural ecosystem recovering.

\section{CONCLUSIONS}

In the present study, the feasibility of CLUE-S model in Panjin was tested as well as used to simulate land use change in Panjin from 2008 to 2018. In the simulation process, driving forces of land use were regarded, including slope, aspect, distance from river, density of population and so on.

The result showed that, the Clue-S model was feasibility to predict the future land use by natural and 
social-economic driving forces. To simulate the land use in 2008, two scenarios were designed. In different scenarios, the future prediction was different. By comparison of the two scenarios, the land use pattern of environmental protection mode was better than development following existing trends mode. The simulations could be the important references for future land use plan.

\section{ACKNOWLEDGEMENT}

The study were supported by the Project fund: the National Water Pollution Control and Treatment Science and Technology Major Project (2013ZX07202-007).

\section{REFERENCES}

[1] Lambin, E.F., Turner, B.L., et al., 2001. The causes of land-use and land-cover change: moving beyond the myths. Global Environmental Change 11:261-269.

[2] Liu, M., Hu., Y.M., Chang, Y., et al. 2009. Land Use and Land Cover Change Analysis and Prediction in the Upper Reaches of the Minjiang River, China. Environmental Management 43:899-907.

[3] Pontius, J.R.G., \& Schneider, L.C., 2001. Land-cover change model validation by an ROC method for the Ipswich watershed, Massachusetts, USA. Agriculture, Ecosystems \& Environment. 85:239-248.

[4] Thompson, R.C., Crowea, T.P., Hawkins, S.J., 2002. Rocky intertidal communities: past environmental changes, present status and predictions for the next 25 years. Environmental Conservation 29:168-191.

[5] Turner II, B. L., 1994. Local faces, global flows: the role of land use and land cover in global environmental change. Land Degradation and Rehabilitation 5:71-78.

[6] Veldkamp, A., Verburg, P.H., Kok, K., et al., 2001. The need for scale sensitive approaches in spatiallyexplicit land use change modeling. Environmental Modeling and Assessment 6:111-121.

[7] Verburg, P.H. \& Veldkamp, A., 2004. Projecting land use transitions at forest fringes in the Philippines at two spatial scales. Landscape Ecology 19:77-98.

[8] Verburg, P.H., Soepboer, W., Limpiada, R., et al., 2002. Land use change modelling at the regional scale: the CLUE-S model. Environmental Management 30: 391-405.

[9] Wu, J. \&Hobbs, R., 2002. Key issues and research priorities in landscape ecology: an idiosyncratic synthesis. Landscape Ecology 17:355-365. 